\title{
The Identity Analysis of Yussef El Guindi's Ten Acrobats in an Amazing Leap of Faith
}

\author{
Yussef El Guindi'nin Ten Acrobats in an Amazing Leap of Faith Oyununun Kimlik Analizi \\ Gamze Ar, Department of Foreign Languages, Bartın University
}

\begin{abstract}
The meaning of home differs from one person to another. America hosts many hybrid cultures and one of them is the Arab American identity. These people suffer from many hardships not only because of their religious differences, but also their traditional alienation to American culture. This paper will analyze the Egyptian-American playwright Yussef El Guindi's play Ten Acrobats in An Amazing Leap of Faith (2018), presenting the fear and anxiety for the unknown culture in an Arab American family who struggle with identity problems and the American lifestyle. The concept of in-betweenness will be analyzed in each character and as Stuart Hall mentioned in his theory, this study will carry out "the eye of the needle of the other before it can construct itself" (1996, p. 89). As for identity framework, each character will be examined in terms of identity, gender and religious perspectives. The hardships of each character throws light on various commentaries in relating to the identity analyses and this study will explicitly show how the concept of identity will be shown with different Arab Americans. The cultural conflict is understood with Arab American identities that captivated the hegemonic Americanized thought system in America. While analyzing all characters in the play, this study will present how El Guindi reflects upon the lives of inbetween Arab Americans with various issues such as religion, gender and race. While studying themes such as identity, religion, gender and race, the framework will be considered according to the theorists like Homi Bhabha, Stuart Hall, Gilles Deleuze and Félix Guattari.
\end{abstract}

Keywords: Otherness, identity, gender, Yussef El Guindi, Ten Acrobats in An Amazing Leap of Faith.

Academical disciplines/fields: American culture, Arab American theatre, identity.

\section{Özet}

Evin anlamı her kişi için farklıdır. Tarih boyunca, Amerika pek çok farklı kültüre ev sahipliği etmiş ve bunlardan birisi de Arap Amerikalılardır. Bu insanlar sadece dinsel farklılıklardan değil, geleneksel yabancılaşmadan dolayı da pek çok zorluklar yașamıșlardır. Bu araștırma Mısırlı Amerikalı oyun yazarı Yussef El Guindi'nin oyunu olan Ten Acrobats in An Amazing Leap of Faith (2018) inceleyecektir. Bu oyun, Amerikan yaşam tarzına alışmaya çalışan ve kimlik problemleri yaşayan Arap Amerikan kökenli bir ailenin bilinmeyen bir kültürdeki korku ve telașını anlatmaktadır. Arada kalmışlık terimi her bir karakterde incelenecek ve Stuart Hall'ın teorisinde bahsettiği gibi çalışma "kendini oluşturmadan önce başkasının gözünü" okuyucuya sunacaktır. (1996, s. 89) Kimlik çerçevesinden bakıldığında, her bir karakter kimlik, cinsiyet ve din gibi farklı yönlerden incelenecektir. Bu karakterlerin çektiği zorluklar kimliksel olarak farklı yorumları aydınlatacak ve açık bir şekilde bu bakıș açısının farklı Arap Amerikalılardaki yansımaları görülecektir. Kültürel çatışma kavramı, Arap Amerikalı kimlikler ile hegemonyan Amerikan düșünce sisteminde hapsolmuș karakterlere ıșık tutmaya çalışacaktır. Oyundaki bütün karakterleri inceleyen çalışma, El Guindi'nin arada kalmıs Arap Amerikalıları din, cinsiyet ve ırk gibi farklı konulara değinerek nasıl ele aldığını gösterecektir. Kimlik, din, cinsiyet ve ırk gibi temaları çalışırken, bu çerçeve Homi Bhabha, Stuart Hall, Gilles Deleuze ve Félix Guattari gibi teorisyenlere göre değerlendirilecektir.

Anahtar Sözcükler: Ötekileșme, kimlik, cinsiyet, Yussef El Guindi, Ten Acrobats in An Amazing Leap of Faith.

Akademik disipin(ler)/alan(lar): Amerikan kültürü, Arap Amerikan tiyatrosu, kimlik.

- Corresponding Author: Gamze Ar, The Department of Foreign Languages, Bartın University.

- Address: Bartın Üniversitesi, Yabancı Diller Yüksekokulu, Ağdacı Kampüs, Bartın.

- $\quad$ e-mail: gamzear@bartin.edu.tr

- ORCID: 0000-0002-8918-2124

- Available online: 21.12 .2021

- doi: $10.17484 /$ yedi.994814 


\section{Introduction}

For each person, home and sense of belonging are defined differently; for instance, some evaluate home as a geographical place, others consider it as the place where they feel comfortable, or home can mean nostalgic feelings. The most significant point here is to explain identity to understand the concept of home better. Stuart Hall (1996, p. 89), defines identity as "the eye of the needle of the other before it can construct itself." Culture shapes identity in that all the practices such as everyday language, beliefs and cultural practices affect people subconsciously. At the end of all immediate effects, people are culturized. Hall states:

Identity is always a temporary and unstable effect of relations which define identities by marking differences. Thus, the emphasis here is on the multiplicity of identities and differences rather than on a singular identity and the connections or articulations between the fragments or differences. (Hall and Gay, 1996, p. 89)

This definition shows how identity has a fluid character because mankind with his mind and body is always a mobile being. Therefore, they are open to diverse experiences. The play is a great projection of the intercultural practices and multiculturalism, and it reveals how each character represents the problems of Arab American identity and from which perspectives they are affected. This research examines the struggles and survival of an Arab American family in terms of four aspects: identity, race, religion, and gender.

Minority groups such as Arab Americans experience some generational conflicts in their families in terms of understanding and adapting to the culture. In the history of Arab Americans, 9/11 in 2001 is the most important tragic event and it is considered as the starting point for the Arab American theater as it reflects the historical prejudices against Arab communities in the U.S. Islamophobia is the peak level in those times and many Arab American playwrights highlight this issue. Another definitive word that indicates the essence of Arab American theatre is transnationalism. This term is explained as "the processes by which immigrants build social fields that link together their country of origin and their country of settlement" (Schiller, Basch and Blanc-Szanton, 1992, p. 1). He also adds that "Transmigrants develop and maintain multiple relations - familial, economic, social, organizational, religious, and political, that span borders. Transmigrants take actions, make decisions, and feel concerns, and develop identities within social networks that connect them to two or more societies simultaneously" (Schiller, Basch and Blanc-Szanton, 1992, p. 1-2). The multiple social communities that connect construct the mosaics of culture in terms of assimilation or acculturation.

Historically, Egyptian Americans are seen as recent comers to the U.S and so they began to emigrate to America in the twentieth century. Because of being far away from their cultures and traditions, they feel alienated in their new country, America. They suffer from various historical chaotic experiences such as the Arab-Israeli War, and their traumatic minds attempt to create a space for living better. Many of them settled down in New York, Florida, California and Texas. Their historical background is narrated by Mikhail as follows:

Although the majority left for economic or educational reasons, many Copts, Jews, and conservative Muslims emigrated because they were concerned about political developments in Egypt. Thousands of others left after Egypt's 1967 defeat in the Arab-Israeli War, with approximately 15,000 Egyptians immigrating to the United States from 1967 to 1977. The following three decades witnessed unprecedented movements of large Egyptian populations not only to the United States and Canada but also to Australia, Europe, and the Gulf Arab countries. Records from 2005 break down the immigration patterns by percentage: 11 percent of Egyptian Americans living in the United States at that time arrived before 1970 . Another 18 percent immigrated in the 1970 s, with the largest percentage-27 percent-arriving in the 1980s. (Mikhail, 2014, p. 62) 
In Ten Acrobats in An Amazing Leap of Faith (2018), the characters are the embodiment of psychologically continuous mobility and fragmented identities. As mentioned in the headline, ten implies the characters' numbers, and each is seen as the acrobat because of acting according to society's regulated roles. At that point, the sending and receiving countries do not harmonize and they create conflict between each other because the cultural and traditional practices have diverse characteristics in terms of revealing the religious and social worldviews. The question of home and belongingness can play important roles in addressing the issue of identity searching in Arab American theatres, and one of them is Yussef El Guindi's Ten Acrobats in An Amazing Leap of Faith. El Guindi has both identities such as Egyptian and American because of being born in Egypt but growing up in America. His play projects the Arab American family drama which deals with different problems in Los Angeles. Ten acrobats, which Guindi refers to each character of the play, suffer from some identity problems and El Guindi reflects this story with sharp humor.

The Introduction part will focus on the play Ten Acrobats in An Amazing Leap of Faith and its writer Yussef El Guindi (1960- ) that are briefly examined with the historical and cultural backgrounds in relating to the Arab American context. After that, the paper will present El Guindi's life to understand better the context of the analysis. Afterward, the main part which is the analysis of Ten Acrobats in An Amazing Leap of Faith will reflect the character analysis via four diverse perspectives such as identity, religion, race and gender. Each constructs the analysis differently. The identity analysis will be seen with significant theorists like Stuart Hall, Gilles Deleuze, Félix Guattari and Julia Kristeva. The eleven characters will be examined with these theorists' cultural practices. The other analysis will be about religion which states how the Arab identities see Islam and, indeed, how America reacts towards them. The racial analysis will be also shown with the discriminated Arab identities in American society. Ethnic diversity always creates a problem in hybrid American life, and El Guindi indicates this multidimensional aspect with perfect illustrations in the play. Lastly, the gender analysis will emphasize the hijab issue in Islam, and it analyzes how Arab American women suffer from the hijab and covering their heads in dominant Christian society. The last part of the study will be the conclusion with the summarizing clues and information about El Guindi's play and analysis. The aim of this paper is to highlight the Arab American struggles within the frame of diverse theories like identity, race, religion and gender.

Yussef El Guindi is an important Egyptian-American playwright in the field of Arab American theatre because his plays are involved in both personal and political outlook. His personal experiences construct the background of his plays and he states: "I see myself as writing in the tradition of the quintessential American narrative, which is primarily the immigrant narrative. That has been my life experience" (Qualey, 2012, para. 12). In his plays, he generally deals with the immigration contexts and identity analysis such as the search of belongingness, otherness, the concept of home, roots, etc. El Guindi is a great playwright with his authentic themes which reflect the conflict between two cultures like Arab and America. His ethnic background and growing up experiences provide to shape his artistic style. He also "the 2009 winner of the Osborn Award by the American Theater Critics Association and 2008 winner of ACT's New Play Award" (Sierra, 2010, para. 5). All these successes indicate how he is a good projector of Arab American experiences, especially the generations collide in Ten Acrobats in an Amazing Leap of Faith.

He generally deals with immigrant experiences and intergenerational conflicts. At that point, the Muslim family life constructs the background of his plays. "Egypt should have felt like home, but with his European childhood and broken Arabic, Mr. El Guindi says in many ways he did not fit in and was called by a mildly derogatory Arabic word for foreigner" (Stack, 2015, para. 10). He determines the atmosphere of his plays with the language choices; for example, he presents the colloquial Arabic speeches in the conversation of Arab Americans and it is the most obvious indicator to imply the characters' identity complexities. Furthermore, he mostly uses traditional motifs and symbols to demonstrate cultural differences such as Islamic motifs or traditional iconographies. The sense of belonging and home are other important themes in El Guindi's plays in that these issues create the in-betweenness in the context of Arab American theatre.

\section{The Analysis of Ten Acrobats in An Amazing Leap of Faith}

Ten Acrobats in An Amazing Leap of Faith (2018) is Yussef El Guindi's play after post 9/11 which can be considered as the starting point for the Arab American theatre. In addition to the historical background of the play, present-time elements such as the special fest Ramadan, family matching marriage, and hijab which is a special cloth for covering women are shown in the play. All these things are the symbolizations of Arab culture, but the problem arises that all of them appear in American society. America is known as the melting pot with embracing many diverse nations; however, these nations start to lose their own cultures and practices under the oppressive and dominant American capitalist system. At that point, the definition 
of assimilation can light on this issue. Sociologically, assimilation "has been defined as a multidimensional process of boundary reduction and brokering which blurs or dissolves an ethnic distinction and the social and cultural differences and identities associated with it" (Rumbaut, 2015, p. 2). The determinative elements such as age, gender, citizenship, and generations can vary in receiving and sending countries, and so these differences create the otherness for Arab Americans in this context. Moreover, the social and political situations of home and host countries provide to understand better the background of play and characters' moods.

The play is mainly about an Arab American family who is suffering from many hardships like inbetweenness, otherness and the complexity of home. Their searching constructs the essential part of the play. This family's parents are Kamal and Mona. The father Kamal is a typical Arab chacrater because he is still using the language of his own nation such as "Assalam alaykum." (El Guindi, 2018, p. 25) On the other hand, the mother Mona seems more adaptable than Kamal. However, she lives her feelings in herself. She is trying to be peacemaker in the family. They have three children: Tawfiq, Huwaida and Hamza. Tawfiq does not believe his Arab American identity. Instead, he thinks himself as an American. He is against Arabic traditions. Huwaida lives in-betweenness with the differences of clothing system and marriage stuffs. The last child is Hamza who cannot determine his sexuality. Besides this main family, there is one more family with Aziz and Murad. The father Aziz tries to make his son marry with Huwaida that these children do not see each other in the beginning of the play. It is a kind of family arranged marriage. This family's males are mentioned and they also suffer from identity problems with Americanization. In the play, there are also some Americanized representations such as the psychologist Pauline, customs officers and cops. These characters are the great symbolizations for indicating the superficial Americanized ideologies such as the prejudiced discourses about Islam or its practices. All these characters will be explained with their identity struggles from the play's dialogues.

\subsection{Identity Analysis}

El Guindi's play is an Arab American drama, mainly involving the issues of family, immigrant, and intergenerational conflicts. He creates ten scenes throughout the play and each of them reflects the state of becoming which can be also integrated with Julia Kristeva's abject position. For Kristeva (1982, p. 2), abject "draws me toward the place where meaning collapses." In the play, El Guindi creates his characters in their destructive worlds that symbolically refer to their fragmentations on the path of identity and home. Transnational identity is an important aspect of stating the collapse of belongingness to somewhere or something. The play's main characters Kamal and Mona are the parents of three children Tawfiq, Huwaida, and Hamza, and all these children are lost in their identity searches as they conflict with their own homeland culture. The parents' Kamal and Mona are first-generation Arab Americans and they are strictly bounded with their cultural identities and Islam. In America, they are still using Arabic words and carrying out the traditional practices such as fasting in Ramadan or praying in their language. On the other side, their children are in different depressions such as atheism, homosexual desires, and the cloth of hijab. Throughout the play, some characters such as psychologist Pauline, the customs officer, and Kevin are seen as the embodiment of prejudiced American society that rises with 9/11 in America. They see Arabs as terrorists and their acts are misunderstood in their outlook. Besides, their religious practices are contrary to the American belief system, and so there is another cause of prejudices that is created by American society.

From the perspective of identity conflict, Kamal and Mona are the authentic figures to be examined in the play. Kamal is the father of the Arab-American family and he strictly carries out the principles of Islam in American society. He also uses Arabic expressions such as "Inshallah...Inshallah" (El Guindi, 2018, p. 25) and "Allah yarhamah" (El Guindi, 2018, p. 93). He also obeys the rules of Ramadan while fasting at that time. He wants to see that all his children follow the Islamic rules and obey himself as the father. However, he is disappointed with their aggressive behaviors which will be explained. Kamal also tries to create his home with some iconographies such as carpet and oud in the play. Thus, it can be said that the sense of belongingness is attached with the iconographic concept as he tries to construct his ideally suitable world with Islamic and Arabic cultural practices in America.

Mona is the mother of this Arab-American family in the play and she is much more modest than Kamal as she does not judge her children except for Huwaida's clothes. She carries out Arabic cultural practices and Islamic rules in her life, but she also adapts to the life of America because of her sympathetic behaviors toward her children. For instance, she tries to stop Kamal's ironic statements to Tawfiq's atheistic beliefs.

KAMAL. Of course, it matters. It matters if our children have become so irresponsible, they don't know how to behave. 
MONA. Kamal, it's the floor. It's dirt, it's not a crisis.

KAMAL. It tells me they have no respect for anything anymore. Were you here the entire time?

MONA. Don't worry about it. (El Guindi, 2018, p. 28)

In this scene, Kamal is angry about his son Tawfiq who behaves inappropriately in the context of Arab traditions. For example, he is not kissing his father's hand or not using Arabic words in his life. As clearly stated in these dialogues, Mona tries to tell that it is not a crisis and she tries to show the respect here or she behaves in this way in case of not extending the discussion between Kamal and Tawfiq. Both of the parents, Mona and Kamal are always changing the furniture, which is the embodiment of their Arabic identities in the play. It is the indicator of their adaptation process in America as they do not get accustomed to living with American cultural practices. This alteration symbolizes their fluidity and 'becoming' process in the Western world. There is always an uncertainty in their identities because they are living in "a process of celebrating dynamic spaces of cultural change characterized by shifting identities" (Kalua, 2009, p. 23). This quotation reflects Homi Bhabha's (1994) third space theory defined "as a metaphorical space in which two or more disparate social or cultural paradigms interact to form new or hybrid ways of thinking or being" (Bhabha, 1994, as cited in Roy, 2017, p. 3). Mona and Kamal create their third space as they are located far away from their home country which is not seen on the map according to the statement of Mona "What roots? These sounds come from a country that is not on the map" (El Guindi, 2018, p. 2).

Unlike Kamal, the mother Mona's roots are everywhere just like rhizome ${ }^{1}$ which is the definition of Deleuze and Guattari in A Thousand Plateaus as she does not want to live in Egypt, but she is still carrying out Arabic principles in her life despite living in America. From the Westernized side, Mona is also a modest and understandable character. Thus, it can be said that she has a much more harmonious nature rather than other characters in the play. Mona, here, uses the performativity which shows her suitable behaviors in the American culture, and her adaptable side with her reactions against Tawfiq and Hamza also makes her Americanize. However, she is strongly against Huwaida's cloth in the play and it can be commented Mona's reaction against Huwaida is the symbolization of subconsciously restricted gender roles in her mind.

Murad and Aziz also live different identity struggles in the same family. They do not live in America, but they are affected by the American popular culture. In the play, they come from Egypt so that the father Aziz wants his son Murad and Huwaida from the Fawzi family to get engaged. However, Huwaida and Murad do not want. At that point, Murad's dream and behaviors indicate how he is afraid of the dominant American culture even though he does not live there. He thinks that he can lose himself in America, and his statement "I'd never survive in America" (El Guindi, 2018, p. 81) clearly explains his anxiety towards the capitalist American society. His emotional weakness and fear are the background of this feeling.

From the aspect of identity analysis, Tawfiq can be seen as self-abjection because he questions God and later rejects it. Julia Kristeva's explanation about the loss abjection states how the self individually experiences the state of loss. Kristeva presents: "The abjection of self would be the culminating form of that experience of the subject to which it is revealed that all its objects are based merely on the inaugural loss that laid the foundations of its own being" (Kristeva, 1982, p. 5). The loss here illustrates the absence of God in that Tawfiq cannot see or understand this phenomenon because of living cultural dilemmas and multiplicity. Moreover, the intergenerational conflict between Kamal and his children explores the idea of incompatible behaviors because Kamal's identity belongs to his home country; on the other side, his children have fragmented identities because of being born into the American lifestyle. Kamal's following statements show his regret of coming to America:

This will be in his record. This - stain. This...abomination. This is public record. You know this is public record? For everyone to see. This will spread like wild fire - in the community, and back to Egypt. Oh, they will love this. We will be the best show in town. We are supplying them with all the drama they need. Switch off your televisions and come see the Fawzi family as they explode. First my son goes insane and becomes an atheist. Then my daughter goes insane and dumps the engagement. And now my other son goes insane and goes fornicating in the bushes. What happened? Did they change the drinking water on us? Is there a

\footnotetext{
1 This philosophical term is created by Gilles Deleuze and Félix Guattari in their Capitalism and Schizophrenia (1972-1980) project. It means multiplicity and connection to any other things in life. There is no strict or boundary here. Thus, rhizome perfectly explains Mona's situation with her unbounded life and desires in life.
} 
virus going round that is affecting our ability to be sane? Decent? Oh. (El Guindi, 2018, p. 84-85)

In the analysis of identities for each character, religion is one of the most significant issues in this play and El Guindi reveals this concept with the use of anger, fear, love, and disappointment. Tawfiq can be the best projection for the fragmentation of religion as he is lost in the religious phenomenon. He is also the representation of religious collapse in Islam. Tawfiq is the son of Kamal and Mona, and he is a secondgeneration Arab American because of being born in America. His religious emptiness causes him to be an atheist in the play and each character reacts towards his atheism differently; for example, Kamal sees this situation as an illness with the statement "I would seek medical advice" (El Guindi, 2018, p. 62). On the other hand, Aziz is curious about atheism and he tells: "Every family should have an atheist. It keeps God's voice fresh and the faithful on their toes" (El Guindi, 2018, p. 97). Aziz's statement can be seen as an ironic commentary in El Guindi's perspective because it manifests how people are oppressed by religious practices and they change their religions in the end. Tawfiq's character embraces the American cultural system because of having free and open-minded ideas. For instance, he is also against the arranged marriage and he tries to meet Huwaida and Murad before their engagement. Even the following brief conversation between Kamal and Tawfiq sheds light on their diverse characters:

TAWFIQ. Hi.

KAMAL. Assalam alaykum. (El Guindi, 2018, p. 25)

Tawfiq does not use any Arabic expression because he does not consider himself as an Arab. He is much more American with his free individual state of being. Tawfiq also approaches the events rationalistically and rationalism is one of the principles in American culture. For example, he states the choices of Hamza, Huwaida, and himself with the following expression "No one was harmed. This isn't a crime" (El Guindi, 2018, p. 85).

There are also some examples showing the prejudgments of America in the play. The first example is the conversation between Pauline and Huwaida, indicating the religious conflict. Pauline explains Islam in her mind as follows:

[...] your religion has stopped being a living, breathing support and has become instead an excuse for men to put down women... It's not okay that we take on the prejudices of one gender and make them our own. So that we women end up being the gatekeepers of our own oppression; to the point that we make of our manacles things of pride and even become vain about it. I don't know how you can call yourself a feminist and say that, and cover yourself as if you have something to be ashamed about, as if you have anything to apologize for. (El Guindi, 2018, p. 72)

Pauline here criticizes Islam in terms of creating taboos for women in society because it is in favor of men. Veiling is seen as covering something ashamed in the Western perspective. Thus, Islam is considered as the opposition to the development of women and feminism in the Westernized thought system. Huwaida in her dream saw herself as wearing a bikini and covering her head. It is a great projection of the clash between two religions in Huwaida's subconscious mind. She cannot explain herself but she is the in-between situation.

The end of the play reveals the theme of universality and it is an absolute message in the play. This unifying theme embraces all kinds of human beings without recognizing their religious or ethnic differences. The most important thing is to share life. In the end, H.D. (Huwaida's Double) states the significance of Ramadan while emphasizing the idea of God and uniting all family members as follows:

The thing I like most about Ramadan?... it encourages you to remember God. [...] But - what really makes Ramadan special for me - is the time just before we eat. When the whole family and the friends you've invited gather around the table and there's this wonderful anticipation of something delicious about to happen. of relief. And bounty. Of something about to be shared. And it's that. That's the thing that makes the month of fasting extra special. The sense in the room that you've all been through something together. Most times of the year you come to the table all in your own little worlds, but at Ramadan - you come to the table experiencing a shared world. [...] (El Guindi, 2018, p. 119-120) 
These statements show not only the moral but also the humanistic message because of gathering all the family together. It is great solidarity especially for Muslims and El Guindi here implies the significance of faith. Even though Arab Americans live far away from their home country, these kinds of activities such as religious practices prevent them to feel like foreigners and construct their little home in America. This home can be considered as the third space in Homi Bhabha's theory. However, there is no clash between the two cultures at the end of the play. Besides, it is all about the Muslim heritage and its practices, and it awakens good feelings and hope for the audience. For Bhabha, third space means "the encounter of two social groups with different cultural traditions and potentials of power as a special kind of negotiation or translation" (Ikas and Wagner, 2009, p. 2). Bhabha's definition is seen in many parts of the play such as the contest of Huwaida's beauty pageant, Hamza's sexual dilemma, and Tawfiq's questioning God. All these examples point out the cross-cultural issues and they bring about the identity crisis for themselves.

Each character is perfectly constructed for revealing the collision of ethnicities. The prejudice of the Western thought system is seen with a customs officer in the dream of Murad who comes to America to get engage with Huwaida. This marriage decision is taken by the parents of children and it reveals how the family is the decision-maker in Arabic culture. In the dream of Murad, a customs officer behaves as if Murad's supposed bag is the bomb squad. In the play, these prejudices are indicated in this way:

CUSTOMS OFFICER. Whose suitcase is this?

MURAD. I didn't come with that.

CUSTOMS OFFICER. Uh-huh. (Into a walkie-talkie.) Bomb squad.

H.D. Murad!

CUSTOMS OFFICER. (To Murad.) Passport please. (Murad searches his pockets for his passport.) (El

Guindi, 2018, p. 78-79)

These dialogues show the post-traumatic 9/11 event in history. In the minds of people, there is still some stereotypical Arab image that causes emotional difficulties. The characters' dreams symbolize their fear of the American culture in which they have to live. Some characters' dreams such as the ones of Huwaida or Murad sheds light on their psychological background. Multicultural outlooks construct their marginalized identities in the minority groups like Arab Americans in this context.

In Ten Acrobats in An Amazing Leap of Faith (2018), it is important to consider how iconographic things such as hijab, Ramadan, oud, mosque create the home and belongingness for the first-generation Arab Americans such as Kamal and Mona. The oud reveals the nostalgia for a homeland because its melodies remind their ancestry. Hijab which is a covering cloth for women represents the religious principles in Islam that are included in the clothing rules such as covering women's head or not drinking alcohol. It causes to feel the otherness for Huwaida in her daily life. In the play, Huwaida is also seen with H.D. and she reflects her anger and fear against hijab and Islam in her dream with H.D. who is Huwaida's Double. In her dream, H.D. wears a bikini and hijab together and it implies the sense of becoming rather than being because of her in-betweenness. It can be said that race or ethnicity comes with religious iconographies and practices, and it creates the characters' subconsciously affected minds.

Kevin is the great symbolization of Arab American's sexual fear in American society because of being a homosexual. He approaches Hamza who plays the oud, and Kevin tries to seduce him. In the conversation between Kevin and Hamza, some statements express Kevin's thoughts about the mythic appearance of the oud. These dialogues are shown with the following statements:

KEVIN. You know, there's a funny myth attached to the invention of the oud. Do you know it? (Kevin holds out the oud. Hamza takes it.)

HAMZA. No.

KEVIN. Well...it is said - the myth goes, that the oud was invented by Lamak, a direct descendant of Cain. The sixth grandson of Adam. And when Lamak's son died, he hung his remains on a tree, for some reason. And when the remains dried out, when they were completely desiccated, the skeleton suggested the form of the oud.... And from that moment on, God gave the sons of Cain the knowhow to make musical instruments. And so... they did. Lamak invented the oud, the drum and the harp. And these instruments became celebrated for treating illnesses. For reviving the heart; invigorating the body. Creating balance. - Fascinating, huh? (El Guindi, 2018, p. 52) 
This Orientalist mythical story starts with Kevin's prejudiced expression such as the "funny myth." Moreover, the religious identities such as Cain and Adam are seen as the parts of mythological story in the eyes of Kevin who is the representation of the dominant Westernized belief system. The conversation between Hamza and Kevin also reflects how Hamza is a passive character in front of Kevin who is an active authority with his speeches and gestures. Also, Kevin does not accept the answer 'San Diego' when Hamza tells them where he is from. Kevin's question "I mean - where's your family from?" typically reflects that Americans do not consider Arab Americans are from anywhere in America. It is a kind of ethnic discrimination.

Gender is another significant point for revealing the characters' fragmented identities. For example, Huwaida's family matching marriage plan and her sufferings with hijab are great projections for demonstrating the domestic nature of women. On the other side, men like Kamal are seen as the leader of the Arab society in that Aziz and Murad come to the engagement rather than women. It sheds light on the patriarchal Arab society like many parts of the world. It is an interesting point that Pauline cannot understand the veiled women and criticizes them despite being a woman. Rather, she is a woman despite her ethnic difference, and her prejudiced commentary about the veiling and hijab makes Muslim women outcasted beings in American society. Another fragmentation in gender is Hamza's homosexuality, and his oppressed sexual desires come from his completely homeless between two countries. Hamza's marginalized identity cannot be seen as normal in both Arab and American societies as the conservative American policies put him in jail in the Reagan times. These gendered choices such as homosexuality are seen as an illness in the eyes of most people and it creates a big problem all over the world.

From the perspective of gender, Huwaida is another victim living inner conflicts. Huwaida is the daughter of Kamal and Mona, and she is a second-generation Arab American. She is studying mathematics besides minoring in art because of her family's artistic background. She is seen as the embodiment of inbetweenness as her dream showing the subconscious field explores her duality like the combination of bikini and veiled cloth. In the dream of Huwaida, her double-conscious character Huwaida's Double appears and this character symbolizes Huwaida's real self in that she reveals the untold speeches which even Huwaida cannot admit herself. Huwaida and H.D. are always in a conflict due to support different world views. Furthermore, veiled figures in the dream are the reflection of the Arab community believing in Islam and its rules. These figures judge H.D. because of breaking the rules of Islam while wearing a bikini or expressing her ideas comfortably. The following dialogue explicitly shows how Huwaida and H.D. are in discussion and veiled figures projects the oppressive Islam religion in the mind of Huwaida:

HUWAIDA. (To Pauline.) And that's the end of the dream.

H.D. No, it's not. I haven't sung yet.

HUWAIDA. (To H.D.) I'm sorry, you're done.

H.D. And I haven't made my speech about making the world a better place.

HUWAIDA. Please get off the stage. (El Guindi, 2018, p. 13)

Huwaida also criticizes the marriage system in America, but later she decides not to get engage with Murad in the family matching procedure. This issue shows that she is neither American nor Egyptian. Her continuous 'becoming' situation indicates her fragmented identity because there are some uncertainties inside her thoughts.

Pauline is the psychologist of Huwaida and she is inquiring what the choices of Huwaida are. She is seen as the embodiment of prejudiced Western thought system because the following statements demonstrates her ideas about the veiled women and Islam:

[...] And I can't imagine that's what any religion is supposed to do. Protect, yes, but imprison? - I am trying to be sensitive to your faith and I know I'm woefully ignorant and God knows we could all do a little more to jump these abysses that separate us but, I do think...I just...I have to come right out and say that I think your religion is bad news for women [...] your religion has stopped being a living, breathing support and has become instead an excuse for men to put down women [...] It's not okay that we take on the prejudices of one gender and make them our own. So that we women end up being the gatekeepers of our own oppression; to the point that we make of our manacles things of pride and even become vain about it. I don't know how you can call yourself a feminist and say 
that, and cover yourself as if you have something to be ashamed about, as if you have anything to apologize for. (El Guindi, 2018, p. 72)

Pauline here judges Huwaida's feminist identity because of her hijab, and indeed, she thinks that Islam captivates women with its principles such as the obligation of veiling. Pauline's statements mentionedabove create the marginalization for Huwaida and they also show how even the psychologist Pauline is the lack of understanding Arab American identities. Pauline does not understand the essence of Islam and she states: "Because I don't see any signs of God in demanding women hide themselves" (El Guindi, 2018, p. 74). It can be said that without internalizing Islam, it is impossible to accept it for American society. It comes from the cultural conflict that the principles of Islam and Christianity opposes between each other. With this quota, it is also seen that America makes Arab Americans otherize and it is the result of prejudiced American society.

Hamza is also seen as the victim of gendered society. He generally plays the oud which is the ancestral musical instrument. Hamza does not question anything else in his life, and he is the victim of religious oppression in that he cannot admit his homosexual desires to himself. His obedient nature makes him a passive human being, unlike Tawfiq. The conversation mentioned-below between Hamza and Kevin shows that Hamza wants to believe in Islam and he does not accept bad thoughts about them:

HAMZA. I have to go home.

KEVIN. Is it a high? Fasting? I'd love to try it one day. I find so much of that culture intriguing. I wish I was a Muslim.

HAMZA. Why?

KEVIN. I don't know. I just think I'd take to it.

HAMZA. Muslims don't do this.

KEVIN. Sure, they do. One of my best lovers was a Muslim.

HAMZA. He wasn't a real Muslim then.

KEVIN. He thought he was. Is that what's troubling you? Not what a devout Muslim does? Is a devout Muslim and a devout human being two different things? It's a shame how so many religions end up being such killjoys.

HAMZA. My religion isn't that.

KEVIN. I can relate. I was a Catholic. I loved the whole thing. Loved the saints, loved praying to Mary. I just couldn't take being called a perpetual sinner. (El Guindi, 2018, p. 55)

For Hamza being Muslim is to obey the rules according to this conversation; however, he recalcitrates the Islamic principles and gets love with Kevin. This situation reveals how he is in-between in terms of religious choices as he does not know how to behave. He tries to carry out the Islamic principles such as fasting or praying, but his sexual desire breaks the rules in Islam. Hamza also keeps silent after having come home from jail and this silent behavior can be seen as his resistance against the oppressive and religious practices. Kevin can be seen as the representation of religious freedom with his homosexual identity here. Furthermore, Kevin, like Pauline, reflects the prejudiced American culture with the question of where Hamza originally comes from. He does not accept San Diego as the answer and this behavior pushes Hamza to feel like an other because he does not belong to America in the eyes of Westernized people.

\section{Conclusion}

The Arab American identity is the state of becoming rather than being because they are always seen as the other and alien in America. For them, not only identity but also religion creates a problem in that their cultural practices are completely different from American practices. Yussef El Guindi's Ten Acrobats in An Amazing Leap of Faith (2018) is a perfect projection of the Egyptian American family which experiences the world of fear, anger, and love. The collision of ethnicities such as Arab and American mostly affects the second-generation Egyptian Americans in terms of creating disillusionment in their lives. The Arab American theatre was born with the event of 9/11 because after this event many Arab American playwrights started to construct networks between each other. El Guindi talking about his opinions on 9/11, says that "For the longest time Arab issues or Muslim issues just had not been on the radar. Then came 9/11. 'Suddenly there were calls for plays.'” (Smith, 2006, para. 3). They generally deal with religious, national, 
and ethnic themes which reveal the idea of belongingness. The identity crisis is seen as the primary result in the Arab American theater in that these people carry out different cultural practices in America. The migrant experiences also present the idea of multiplicity and transnational identities in addition to the migrant's adaptation processes.

In El Guindi's Ten Acrobats in An Amazing Leap of Faith (2018), each character draws an authentic image in the eyes of audiences; for example, the second-generation children such as Tawfiq, Huwaida, and Hamza are the embodiment of American society's victims. There is no beginning and ending for them; these generations are the projection of in-betweenness. In this context, the home country is Egypt whose religion is Islam and it is ruled under the patriarchal system; on the other side, America is the country of freedom. These distinctions between receiving and sending countries create the psychological emptiness in the characters' mental states. The first generations like Mona and Kamal differently experience rather than their children. For example, both use Arabic words in their daily lives. However, Kamal has a nostalgia for his home country; on the other side, Mona thinks that it was the right choice to come to America because of Egypt's tumultuous historical complexities. Thus, it is important to understand the background of migration experiences.

Yussef El Guindi is a significant playwright in the field of diasporic studying and he examines the meaning of home and hybrid identities. Immigrants' explorations of their selves are the main problems for achieving their identities. They are still using their language in America and it can be seen as a resistance to the mainstream American culture. They try to protect their own cultures and El Guindi addresses them as acrobats who perform the great balance on a thin rope. This resemblance implies how the characters strive to balance between two cultures. El Guindi's great simile shows his genius ability and he also merged this simile with the faith which creates the irony here as many characters' faiths are in the fragmented structure. It can be said that they search for who they are and where they belong to. The study offers some important insights into the identity analysis and diasporic studying of Arab American theatre. El Guindi states his ideas about the invisibility of Arab Americans as follows:

Because there are so few depictions of Arab American life in our theater, people have wanted me to give it a very, very affirmative view of who we are... But in order to humanize a people, you need to show them warts and all. Our humanity lives in our cracks and wounds. How can you affirm something without talking about everything? (Hill, H. and Amin D, 2009, p. xxvi)

It is seen that Arab Americans want to be visible in America and Arab American playwrights such as El Guindi achieve it with their masterpieces. The self-identification with these kinds of plays attributes the authentic symbolization for Arab Americans, and Ten Acrobats in An Amazing Leap of Faith is one of the plays revealing the immigrant family drama. All characters experience cultural conflicts from diverse sides and each is the embodiment of marginalized fragmented life in America. With America's mosaics in its culture, it becomes a complicated nation for immigrants living in America. El Guindi's play is one of them that suffers from the identity crisis and in-betweenness with the alienated Americanized behaviors. Immigrant experiences arise from the search for a new place, and people had to leave their home countries because of some reasons such as historical oppressions, economic problems or social fragmentations in themselves. El Guindi explores the idea of home and feeling alien or outcast with different traditional practices. He emphasizes these people are in the process of becoming rather than being because they always search for their belongingness psychologically and psychically. Thus, it is fundamental to say that there is no definitive point of view for the Arab Americans as they are in-between nations.

\section{References}

Bhabha, H. K. (1994). The location of culture. Routledge.

El Guindi, Y. (2018). Ten acrobats in an amazing leap of faith. Robert A. Freedman Dramatic Agency.

Hall, S. and Gay, P. D. (Eds.). (1996). Questions of cultural identity. Sage.

Hill, H. and Amin D. (2009). Salaam. Peace an anthology of Middle Eastern-American drama. Theatre Communication Group.

Ikas, K. and Wagner, G. (Eds.). (2009). Communicating in the third space. Routledge.

Kalua, F. (2009). Homi Bhabha's third space and African identity. Journal of African Cultural Studies Publication, 21(1), p. 23-32. 
Kristeva, J. (1982). Powers of horror a essay on abjection (L. S. Roudiez, Trans.). Columbia UP.

Mikhail, M. (2014). Egyptian Americans. In T. Riggs (Ed.), Gale encyclopedia of multicultural America (3rd Ed.) (pp. 61-71). Gale.

Roy, B. K. (2017). Cultural identity and third space: An exploration of their connection in a title I school. [Doctoral Dissertation, Arizona State University]. ProQuest Dissertations and Theses database (Order No. 10607271).

https://www.proquest.com/openview/044ab6cd6f38d32b60e091aaad9da06b/1?pqorigsite $=$ gscholar $\&$ cbl $=18750$

Rumbaut, R. G. (2015). Assimilation of immigrants. In James D. Wright (Ed.), International encyclopedia of the social \& behavioral sciences (2nd Ed.) (pp. 81-87). https://ssrn.com/abstract=2595896

Schiller, N. G., Basch, L. and Blanc-Szanton, C. (1992). Transnationalism: A new analytic framework for understanding migration. Annals of the New York Academy of sciences, 645 (1), pp. 1-24. doi:10.1111/j.1749-6632.1992.tb33484.x

Sierra, G. (2010, May 18). ACT \& Icicle creek announces new play festival: An uncorked conversation 8/23, 8/24. Broadway world Seattle. https://www.broadwayworld.com/seattle/article/ACT-IcicleCreek-Announces-New-Play-Festival-An-Uncorked-Conversation-823-824-20100518

Smith, D. (2006, February 11). For Arab-American playwrights, a sense of purpose. The New York Times. https://www.nytimes.com/2006/02/11/theater/newsandfeatures/for-arabamericanplaywrights-a-sense-of-purpose.html

Stack, L. (2015, July 29). In Yussef El Guindi's plays, personal and political are in bed together. The New York Times. https://www.nytimes.com/2015/08/02/theater/in-yussef-el-guindis-threesomepersonal-and-political-are-in-bed-together.html

Qualey, M. L. (2012, April 15). Yussef El Guindi: Staging the Egyptian-American experience. Egypt Independent. https://egyptindependent.com/yussef-el-guindi-staging-egyptianamericanexperience/ 